\title{
Kadınların Prenatal Kayıp Durumunda Ebelerden Beklentileri
}

\section{Expectations of Women Living Prenatal Loss from Midwives}

\author{
Hülya Ayçiçek ${ }^{1 *}$, Ayden Çoban ${ }^{2}$ \\ ${ }^{1}$ İstanbul İl Sağlık Müdürlüğü Halk Sağlığı Hizmetleri Başkanlığı, İstanbul, Türkiye \\ ${ }^{2}$ Aydın Adnan Menderes Üniversitesi Sağlık Bilimleri Fakültesi, Ebelik Bölümü, Aydın, Türkiye \\ e-mail: hlyaycck@gmail.com, ayden.coban@adu.edu.tr \\ ORCID: 0000-0003-3292-9191 \\ ORCID: 0000-0002-2189-2488 \\ *Sorumlu yazar/ Corresponding Author: Hülya Ayçiçek \\ Gönderim Tarihi / Received: 16.06.2020 \\ Kabul Tarihi / Accepted: 19.10.2020
}

DOI: $10.34087 /$ cbusbed. 753720

\begin{abstract}
Giriș ve Amaç: Bu araştırmada kadınların prenatal kayıp durumunda ebelerden beklentilerini belirlenmiştir. Gereç ve Yöntemler: Araştırma analitik kesitsel olarak Eylül 2015 - Temmuz 2019 tarihleri arasında Gaziosmanpaşa İlçe Sağlık Müdürlüğü'ne bağlı 24 Aile Sağlığı Merkezi (ASM)'nde gerçekleştirilmiştir. Araştırmaya ASM'lere başvuran, araştırmaya katılmayı kabul eden 20 yaş ve üzeri evli olan 434 kadın alınmıştır.

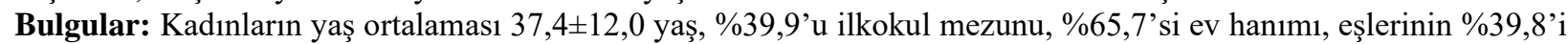
ilköğretim mezunu, \%42,6'sı serbest meslek sahibi olduğu belirlenmiş ve \%50,7'sinin geliri gidere denk algıladığ1, \%86,6'sının sosyal güvencesinin olduğu saptanmıştır. Kadınların \%94,9'unun gebelik geçirdiği, \%45,6'sının gebelik kaybı yaşadığı bulunmuştur. Yaşanılan gebelik kaybının nedeni sorgulandığında; \%34,0’ünün kayıp nedenini bilmediği belirlenmiştir. Kadınların bu süreçte sağlık kuruluşuna başvuru oranı \%86,6'dır. Sağlık kuruluşunda kendisi ile ilgilenen sağlık personelinin kim olduğu sorgulandığında; kadınların \% 7,8'i bu kişinin ebe olduğunu ifade etmiştir. Gebelik kaybına ilişkin kadınların \%37,9'u danışmanlık almıştır. Kadınların \%55,4'ü gebelik kaybı ile ilgili ebelerin yaklaşımını bilmiyorum şeklinde yanıtlamış ya da soruyu cevapsız bırakmıştır. Prenatal kayıp yaşayan kadınlar ile kayıp yaşamayan kadınların ebelik yaklaşımına ilişkin olumlu iletişim, izlem ve bakım beklentisi her iki grup bakımından benzer bulunmuştur. Psikolojik destek, danışmanlık ile eğitim beklentilerine bakıldığında ise gruplar arasındaki farkın anlamlı olduğu saptanmıştır.

Sonuç: Araştırmada, tüm kadınların ebelerden olumlu iletişim, izlem ve bakım beklentisi olduğu ancak prenatal kayıp yaşayan kadınların bunlara ek olarak psikolojik destek, danışmanlık ve eğitim beklentilerinin kayıp yaşamayan kadınlara göre daha fazla olduğu sonucuna ulaşılmıştır.
\end{abstract}

Anahtar kelimeler: Beklenti, Ebelik, Kadın, Ölüm, Prenatal kayıp, Yas

Abstract
Objective: The objective of this study was to determine the expectations of women from midwives in case of prenatal
loss.
Materials and Methods: The research was conducted as analytical cross-sectional study between September 2015
and July 2019 in 24 Family Health Centers (FHC) affiliated to Gaziosmanpaşa District Health Directorate. This study
recruited married women aged 20 and over who applied to Family Health Center and accepted to participate in the
study.
Results It was determined that the average age of women was $37,4 \pm 12,0$ years, $39,9 \%$ were primary school
graduates, $65,7 \%$ were housewives, $39,8 \%$ of their spouses were primary school graduates, $42,6 \%$ of them were
self-employed and $50,7 \%$ perceived their income as equivalent to their expenses and $86,6 \%$ had social security. It
was found that $94,9 \%$ of women had pregnancy, $45,6 \%$ had pregnancy loss and when the type of their loss was
questioned, the mean number of spontaneous abortion(or miscarriage). When the participants were questioned about
the cause of pregnancy loss, it was found that $34,0 \%$ did not know the cause of their loss. The rate of women applying
to the health facility during this period was $86,6 \%$. When the participants were questioned about the health personnel
who took care of them at the health facility, $7,8 \%$ of women stated that this person was a midwife. $37,9 \%$ of the


women received counseling regarding their pregnancy loss. 55,4 \% of the women answered that they did not know the midwives' approach to pregnancy loss or left the question unanswered. The expectation of positive communication, follow-up and care expectations about the midwifery approach among the women who had prenatal loss and the women who had not lost was found to be similar in both groups. Upon looking at women's expectations of psychological support, counseling and education, the difference between the groups was found to be significant.

Conclusion: In this study, it was concluded that all women had expectations of positive communication, follow-up and care from midwives but women who had prenatal loss had higher psychological support, counseling and education expectations than women who had not lost.

Keywords: Death, Expectation, Grief, Midwifery, Prenatal loss, Women

\section{Giriş}

Kayıp, birey için değerli olan birisinden ya da bir şeyden mahrum olunması ya da bunları kazandiktan sonra kaybedilmesi durumunda ortaya çıkmaktadır. Tanım basit gibi görünmekle birlikte, kaybı ya da kayıpları sarmalayan duygular oldukça karmaşıktır [9]. Prenatal dönemde fetüsün ölümü doğum eylemi başlamadan önce gerçekleşebileceği gibi doğum sırası veya doğum sonrası ilk yedi gün içinde gerçekleşmektedir [21]. Tüm dünyada gebeliklerin \%20-25'i istemsiz düşük, diş gebelik, ölü doğum ve neonatal ölüm gibi nedenlerle kaybedilmektedir [5]. Türkiye Nüfus ve Sağlık Araştırmaları (TNSA) 2018 verilerine göre ülkemizde düşük oranı 13,0, ölü doğum oranı 1,0 ve perinatal ölüm hızı ise binde 9,3 olarak bildirilmiş, son yayımlanan Sağlık İstatistikleri Yıllığ1 2018 verilerine göre ise perinatal ölüm hızının aynı kaldığ́1 görülmüştür.

Gebelik haftası ve kayıp sayısı ne olursa olsun kadınlar, prenatal kayıplara tıpkı bir bebek öldüğünde, onunla ilgili hayallerini, umutlarını kaybettiklerinde olduğu gibi tepki vermektedirler [5, 17]. Kadınlar sadece bebeklerini değil, annelik rollerini, gebelik durumunu, genlerine ve bedenlerine olan güvenlerini de kaybederler $[5,8,10]$. Tüm kadınların dörtte birinden fazlasının yaşamları boyunca düşük, ölü doğum veya bebek ölümünü deneyimlediği düşünülmektedir. Kayıp çoğunlukla yas ve depresyon gibi yoğun emosyonel (ruhsal) yanıtlara yol açabilmektedir [21].

Prenatal kaybın kadın ve eşinin ruh sağlığ üzerinde yıkıcı etkileri, sadece kaybın meydana geldiği dönemle sınırlı olmayıp, gelecekteki tüm gebeliklerde düşünülmesi gereken bir durumdur [12]. Kayıp yaşayan ailelerin gereksinimi olan bilgilendirilme, danışmanlık alma ve annenin bakım gereksinimlerinin karşılanması ebelerin öncelikli görevleri olduğunu göz önüne alırsak, ebelerin bu ailelere yaklaşımda ne kadar önemli rol oynadıkları ortaya çıkmaktadır. Aileler bu dönemde kayıpla ilgili duygularını onları yargılamadan dinleyecek, kendileri ve bebekleri için en doğru kararları vermelerine zaman ve ortam yaratacak, onları hakları konusunda bilgilendirecek önyargısız, pratik ve gerçekçi ebelik yaklaşımlarına gereksinim duymaktadırlar [8]. Ebe ve sağlık profesyonellerinin gebelik kaybı yaşayan kadın ve ailesine yaklaşım konusundaki deneyim, görüş, tutum ve davranışlarına yönelik yapılan literatür incelemesi bu konuda eksiklikleri ortaya koymaktadır. Ebe ve konu ile ilgili sağlık profesyonellerinin konumları gereği prenatal kayıplara ilişkin daha fazla araştırma yapması, kadın ve aile sağlığının geliştirilmesine katkı sağlaması gerekmektedir [13].
Tüm bu bilgiler 1şı̆̆ında, kayıp yaşayan kadınların görüş ve beklentilerine yönelik ebelik hizmetlerinin yapılandırılması, ebelerin mesleki donanımlarının güçlendirilmesi kadın ve toplum sağlığı bakımından oldukça önemlidir. Araştırmanın amacı, kadınların prenatal kayip durumunda ebelerden beklentilerini belirlemektir.

\section{Materyal ve Metot}

$\mathrm{Bu}$ çalışma için Adnan Menderes Üniversitesi Tıp Fakültesi Girişimsel Olmayan Klinik Araştırmalar Etik Kurulu'ndan 05.01.2017 tarihinde ön onay (Protokol No: 2017/1040), araştırmanın Gaziosmanpaşa İlçe Sağlık Müdürlüğü'ne bağlı faaliyet gösteren Aile Sağlığg Merkezleri (ASM)'nde gerçekleşebilmesi için İstanbul İli Sağlık Müdürlüğü Sağlık Hizmetleri Başkanlığg Araştırma Geliştirme (AR-GE) ve Projeler Birimi'nden 22.09.2017 tarihinde yazılı izin alınmış ve karşılıklı protokol imzalandiktan sonra yürütülmüştür. Araştırmanın verileri Eylül 2015 - Temmuz 2019 tarihleri arasında Gaziosmanpaşa İlçe Sağlık Müdürlüğü’ne bağlı 24 ASM'de toplanmıştır.

Araştırmaya ASM'lere başvuran, araştırmaya katılmayı kabul eden 20 yaş ve üzeri evli, belirgin fiziksel ya da ruhsal hastalığı bulunmayan ve canlı doğum sonrası kayıp yaşamamış 434 kadın alınmıştır.

Kadınların tamamen şans faktörüne bağlı şekilde atanmasını gerçekleştirmek ve seçim taraflılığını önlemek için gelişigüzel örnekleme yöntemi ile çalışma grubuna dâhil edilmişlerdir. Veri toplama süresince karşılaşılan 68 göçmen kadının (Suriyeli, Afgan vb.) Türkçe konuşamaması, 24 kadının çalışmaya katılmayı kabul etmemesi, 9 kadının ise 20 yaş altı olması ve 6 kadınında canlı doğum yaptıktan sonra kayıp yaşaması nedenleriyle araştırmaya alınmamıştır.

ASM'ye izlem için başvuran kadınlara araştırma konusunda bilgi verilmiş ve yazılı onamları alınarak anket formları yüz yüze görüşme tekniği kullanılarak doldurulmuştur.

Verilerin Toplama Araçları

Araştırma verilerinin toplanması için literatür taraması ile oluşturulan Tanıtıcı Bilgi Formu kullanılmıştır [1, 3, 19]. "Tanıtıcı Bilgi Formu" (EK 1) kadının özelliklerini tanımlayabilmek için araştırmacı tarafından hazırlananmış olup iki bölümden oluşmaktadır.

Birinci bölüm kadınların sosyo-demografik ve obstetrik özelliklerini (yaş, eğitim durumu, meslek, sağlık güvencesi, eşinin yaşı, eşinin eğitim durumu, eşinin işi, evlilik süresi, aile tipi, gelir durumu, gebelik, canlı doğum, 
yaşayan çocuk, planlı gebelik olup olmadığını) sorgulayan 15 soruyu kapsamaktadır.

İkinci bölüm gebelik deneyimlerini (gebelik kayb1, gebelik kaybı tipleri, kayıp sayıları, kayıp nedenleri, destek sistemleri, sağlık kuruluşu başvurusu, hangi sağlık kuruluşu, ilgilenen sağlık personeli, sağlık kuruluşunda bilgilendirme yapılıp yapılmadığı, kadınların düşüncelerini paylaşıp paylaşamadığı, kayıplara yönelik danışmanlık yapılıp yapılmadığı, ASM'de çalışan ebelerin kayıp hakkında kadınlar ile görüşüp görüşmediği, görüşme yapan kadınların ebelerin yaklaşımını nasıl değerlendirdiği ve kadınların ebelik yaklaşımına ilişkin görüşlerini) sorgulayan 13 soruyu kapsamaktadır.

Istatistiksel Değerlendirme

Araştırmadan elde edilen verilerin analizi istatistik paket programı Statistical Package for the Social Sciences (SPSS) 22,0 kullanılarak yapılmıştır. Çalışmanın verileri ortalama \pm standart sapma, $n$ ve yüzde dağılımı şeklinde sunulmuş olup istatistiksel analizlerde Ki-kare testi kullanılmıştır. İstatistiksel değerlendirmede anlamlılık düzeyi $\mathrm{p}<0,05$ olarak alınmıştır.

\section{Bulgular ve Tartışma}

Araştırma 434 kadınla tamamlanmıştır. Bu kadınların yaş ortalaması 37,4 $\pm 12,0$ yaştır. Katılımcıların \%11,1'inin okuryazar olmadığ1, \%39,9'unun ilkokul ve \%10,8'inin üniversite ve üzeri bir okuldan mezun olduğu

belirlenmiştir. Çalışmaya katılan kadınların \%65,7'sinin ev hanımı, \%12,7'sinin işçi ve \%11,5'inin serbest meslek sahibi olduğu saptanmıştır (Tablo 1).

Eşlerin çoğunluğu ilkokul mezunu ve serbest meslek sahibi olduğu tespit edilmiştir. Yaşadıkları aile tipi \%80,9'nun çekirdek aile, \%9,7'sinin geniş aile, \%9,4'ünün parçalanmış aile şeklindedir. Evlilik süresi ortalaması $15,3 \pm 12,5$ yıl, kadınların ilk evlilik yaşı ortalamas1 21,0 \pm 4,6'dir (Tablo 2).

Kadınların \%94,9'u gebelik geçirmiş ve \%61,3'ünün gebelikleri planlı iken \%38,7'sinin gebeliği planlanmadığı görülmüştür. Gebelik sayılarının ortalaması $3,0 \pm 1,9$, toplam doğum sayılarının ortalaması 2,3 $\pm 1,2$ ve yaşayan çocuk sayısının ortalaması 2,3 \pm 1,2 olarak bulunmuştur (Tablo 3).

Araştırmaya katılan kadınların \%54,4'ünün gebelik kaybı yaşamadığı, \%45,6'sının gebelik kaybı yaşadığ görülmüştür. Kayıp yaşayan kadınların yaşadıkları kayıp türü sorgulandığında kendiliğinden düşük sayısının ortalaması $1,7 \pm 1,1$, isteğe bağlı düşük sayısının ortalaması $1,3 \pm 0,6$ ve ölü doğum sayısının ortalaması $1,1 \pm 0,3$ olarak tespit edilmiştir. Kayıp öyküsü olan kadınların yaşadıkları gebelik kaybının nedenine ilişkin bilgileri sorgulandığında \%34,0’ü kayıp nedenini bilmiyorum, \%15,9’u ağr1/kanama ve \%12,7'sinin gebeliğe ilişkin fizyolojik sorunlar (rahimde yapışılklık, dış gebelik, hipertansiyon vb.) şeklinde yanıt vermiştir. $\mathrm{Bu}$ süreçte kadınların destek aldıkları kişileri sorguladığımızda \%46,2'si eş, \%42,0'si aile üyeleri, $\% 11,7$ 'si arkadaşlarından destek alırken \%21,2'sinin ise hiç kimseden destek almadığg görülmüştür (Tablo 4).
Tablo 1. Kadınların sosyo-demografik özelliklerinin dağılımı $(n=434)$

\begin{tabular}{|c|c|c|}
\hline \multicolumn{3}{|c|}{ Sosyo-Demografik Özellikler } \\
\hline \multirow{2}{*}{\multicolumn{3}{|c|}{$\begin{array}{l}\text { Yaş Ortalaması: } \\
37,4 \pm 12,0 \text { yaş (min: } 20 \text { max: } 69)\end{array}$}} \\
\hline & & \\
\hline & $\mathbf{n}$ & $\%$ \\
\hline \multicolumn{3}{|l|}{ Yaş Grubu } \\
\hline $20-25$ yaş & 67 & 15,4 \\
\hline $26-35$ yaş & 155 & 35,7 \\
\hline $36-45$ yaş & 108 & 24,9 \\
\hline 46-55 yaş & 55 & 12,7 \\
\hline 56 yaş ve Üzeri & 49 & 11,3 \\
\hline
\end{tabular}

\begin{tabular}{|l|l|l|}
\hline Eŭitim Durumu & \multicolumn{2}{l}{} \\
\hline İlköğretim & 48 & 11,1 \\
\hline Ortaokul & 173 & 39,9 \\
\hline Lise & 72 & 16,6 \\
\hline Üniversite ve Üzeri & 94 & 21,7 \\
\hline
\end{tabular}

\begin{tabular}{|c|c|c|}
\hline Meslek & 285 & 65,7 \\
\hline Ėşçi Hanımı & 55 & 12,7 \\
\hline Memur & 32 & 7,4 \\
\hline Serbest Meslek & 50 & 11,5 \\
\hline Diğer (Özel Sektör, Emekli) & 12 & 2,8 \\
\hline Sağlık Güvencesi & & \\
\hline Var & 376 & 86,6 \\
\hline Yok & 58 & 13,4 \\
\hline
\end{tabular}


Tablo 2. Kadınların eş ve aile özelliklerinin dağılımı $(\mathrm{n}=434)$

\begin{tabular}{|lll|}
\hline $\begin{array}{l}\text { Eş ve Aile Özellikleri } \\
\text { Eşinizin eğitim durumu* }\end{array}$ & n & \% \\
\hline Okur Yazar Değil & & \\
\hline İlköğretim & 24 & 5,6 \\
\hline Ortaokul & 172 & 39,8 \\
\hline Lise & 65 & 15,0 \\
\hline Üniversite ve Üzeri & 119 & 27,5 \\
\hline
\end{tabular}

\begin{tabular}{|lll|}
\hline Eşinizin mesleği* & & \\
\hline İşçi & 146 & 33,8 \\
\hline Memur & 42 & 9,7 \\
\hline Serbest Meslek & 184 & 42,6 \\
\hline Diğer (Emekli, İşsiz, Özel Sektör) & 60 & 13,9 \\
\hline
\end{tabular}

\begin{tabular}{|c|c|c|}
\hline Gelir durumu & 200 & 46,1 \\
\hline Gelir Giderden Az & 220 & 50,7 \\
\hline Gelir Gidere Denk & 14 & 3,2 \\
\hline Gelir Giderden Fazla & & \\
\hline
\end{tabular}

\begin{tabular}{|c|c|c|}
\hline Aile tipi & & \\
\hline Çekirdek Aile & 351 & 80,9 \\
\hline Geniş Aile & 42 & 9,7 \\
\hline Parçalanmış Aile & 41 & 9,4 \\
\hline
\end{tabular}

Evlilik süresi ortalaması (yıl):

15,3 $\pm 12,5$ (min: 1 max: 50 )

\begin{tabular}{|c|c|c|}
\hline Evlilik süresi* & & \\
\hline 5 yıl ve daha az & 127 & 29,4 \\
\hline $6-10$ y1l & 76 & 17,6 \\
\hline $11-20 \mathrm{y} 1 \mathrm{l}$ & 104 & 24,1 \\
\hline $21-30 \mathrm{y} 11$ & 61 & 14,1 \\
\hline 31 yıl ve daha fazla & 64 & 14,8 \\
\hline
\end{tabular}

İlk Evlilik Yaşı Ortalaması (yaş):

21,0 \pm 4,6 (min: 14 max: 38)

İlk evlilik yaşı

\begin{tabular}{lll}
18 yaşından küçük & 97 & 22,4 \\
\hline $18-20$ yaş & 148 & 34,1 \\
\hline $21-25$ yaş & 109 & 25,1 \\
25 yaşından büyük & 80 & 18,4
\end{tabular}

* Çalışmaya katılan 2 kadın eşinden boşandığı için ilgili soruları cevapsız bırakmıştır.
Tablo 3. Kadınların obstetrik özelliklerinin dağılımı $(n=434)$

\begin{tabular}{|c|c|c|}
\hline Obstetrik Özellikler & $\mathbf{n}$ & $\%$ \\
\hline \multicolumn{3}{|l|}{ Gebelik Öyküsü } \\
\hline Evet & 412 & 94,9 \\
\hline Hayır & 22 & 5,1 \\
\hline \multicolumn{3}{|c|}{ Gebeliğin (lerin) Planlanma Durumu* } \\
\hline Evet & 253 & 61,2 \\
\hline Hayır & 159 & 38,8 \\
\hline
\end{tabular}

Toplam Gebelik Sayısı Ortalaması:

3,0 $\pm 1,9$ (min: 1 max: 13)

Toplam Gebelik Sayısı*

\begin{tabular}{|l|c|c|}
\hline 1,00 & 77 & 18,7 \\
\hline 2,00 & 133 & 32,3 \\
\hline 3,00 & 79 & 19,2 \\
\hline 4,00 & 50 & 12,1 \\
\hline 5 ve Üzeri & 73 & 17,7 \\
\hline
\end{tabular}

Toplam Doğum Sayısı Ortalaması:

2,3 $\pm 1,2$ (min: 1 max: 9)

Toplam Doğum Sayısı**

\begin{tabular}{|lcc|}
\hline 1,00 & 83 & 24,1 \\
\hline 2,00 & 145 & 42,0 \\
\hline 3,00 & 68 & 19,7 \\
\hline 4 ve Üzeri & 49 & 14,2 \\
\hline
\end{tabular}

Yaşayan Çocuk Sayısı Ortalaması:

2,3 $\pm 1,2$ (min: 1 max: 9)

Yaşayan Çocuk Sayısı**

\begin{tabular}{|c|c|c|}
\hline 1,00 & 84 & 24,3 \\
\hline 2,00 & 142 & 41,2 \\
\hline 3,00 & 72 & 20,9 \\
\hline 4 ve Üzeri & 47 & 13,6 \\
\hline
\end{tabular}

*Gebelik geçirmeyen kadınlar soruyu boş bırakmıştır. ** Gebeliği devam eden, kayıp yaşayan ve gebelik geçirmemiş olan kadınlar soruyu boş bırakmıştır 
Tablo 4. Kadınların gebelik kayıplarına ilişkin özelliklerinin dağılımı (n=188)

\begin{tabular}{|c|c|c|}
\hline Gebelik Kayıplarına İlişkin Özellikler & $\mathbf{n}$ & $\%$ \\
\hline \multicolumn{3}{|l|}{ Gebelik Kaybı Yaşama Durumu** } \\
\hline Evet & 188 & 45,6 \\
\hline Hayır & 224 & 54,4 \\
\hline \multicolumn{3}{|l|}{ Kendiliğinden Düşük Öyküsü* } \\
\hline Evet & 165 & 87,7 \\
\hline Hayır & 23 & 12,23 \\
\hline \multicolumn{3}{|c|}{ Kendiliğinden Düşük Sayısı Ortalaması: $1,7 \pm 1,1$ (min: 1 max: 6) } \\
\hline \multicolumn{3}{|l|}{ Kendiliğinden Düşük Sayısı } \\
\hline 1,00 & 96 & 58,2 \\
\hline 2,00 & 37 & 22,4 \\
\hline 3,00 & 14 & 8,5 \\
\hline 4,00 & 14 & 8,5 \\
\hline 5,00 & 3 & 1,8 \\
\hline 6,00 & 1 & 0,6 \\
\hline \multicolumn{3}{|l|}{ İsteyerek Düşük Öyküsü* } \\
\hline Evet & 27 & 14,3 \\
\hline Hayır & 161 & 85,7 \\
\hline \multicolumn{3}{|c|}{ İsteyerek Düşük Sayısı Ortalaması: $1,3 \pm 0,6(\min : 1 \max : 3)$} \\
\hline \multicolumn{3}{|l|}{ İsteyerek Düşük Sayısı } \\
\hline 1,00 & 20 & 74,1 \\
\hline 2,00 & 5 & 18,5 \\
\hline 3,00 & 2 & 7,4 \\
\hline \multicolumn{3}{|l|}{ Ölü Doğum Öyküsü* } \\
\hline Evet & 20 & 10,7 \\
\hline Hayır & 168 & 89,3 \\
\hline
\end{tabular}

Ölü Doğum Sayısı Ortalaması: $1,1 \pm 0,3$ (min: 1 max: 2)

Ölü Doğum Sayısı

1,00

$17 \quad 85,0$

2,00

$3 \quad 15,0$

Gebelik Kaybı Nedeni*

Ağır Kaldırma / Düşme

Ağrı / Kanama

Fetal Nedenler

Fizyolojik Nedenler (Rahimde Yapışıklık, Dış Gebelik, Hipertansiyon vb)

Psikolojik Nedenler (Stres, Aile İçi Sorunlar, Ebeveynliğe Hazır Olmama vb)

Şiddet

Dini İnanç

Malpraktis / Teratojenik İlaç Kullanımı

İsteğe Bağlı

Bilmiyorum

Gebelik Kaybında En Çok Destek Veren Kişi/Kişiler*

Eş

Aile Bireyleri

Arkadaşlar

Sağlık Personeli

$10 \quad 5,3$

Hiç kimse

$40 \quad 21,2$

*Birden fazla cevap verilmiştir.

**Gebelik geçirmeyen kadınlar soruyu boş bırakmıştır. 
Kadınların yaşanılan gebelik kaybı ile ilgili sağlık kuruluşuna başvuru oranı \%86,6'dır. Başvurulan sağlık kuruluşu \%45,7 devlet hastanesi, \%30,2 özel kurumlar ve \%2,5 ASM'dir. Kadınların gebelik kaybı sürecinde başvurduğu sağlık kuruluşunda kendisi ile ilgilenen sağlık personeli \%34,3'nün doktor; $\% 18,2$ 'sinin hemşire ve \%7,8'inin ebedir. Sağlık kuruluşunda gebelik kaybı ile ilgili düşüncelerini paylaşabilenlerin oranı $\% 41,4$ iken paylaşamamış olanların oranı \%58,6'dır. Başvurulan sağlık kuruluşunda gebelik kaybına ilişkin \%37,9'u danışmanlık almış, danışmanlık alan kadınların hangi konu/konularda danışmanlık aldığı sorgulandığında \%13,8'i kanama takibi/ hijyen/ beslenme, \% 7,4'ü Aile Planlaması (AP)/cinsel yaşam, \%5,3'ü psikolojik destek ve \%4,7'si genetik araştırma yapılmasının gerekliliği yönünde danışmanlık aldığını belirtmiştir. Gebelik kaybı yaşanılan süreçte, bağlı bulunduğu ASM ebesi ile görüşme yapanların oranı $\% 44,5$ iken yapılan görüşmenin konusu olarak \%18,0'i gebeliğginin sonlandığını bildirmiş, \%9,0’u AP, $\% 3,7$ 'si de genetik araştırma konusunda bilgi verildiğini ifade etmiştir (Tablo 5).

Tablo 5: Kadınların kayıp sürecinde sağlık kuruluşu başvurusu ile bilgi alma durumlarının dağılımı $(\mathrm{n}=188)$

\begin{tabular}{|c|c|c|}
\hline Kayıp Yaşayan Kadınların Sağlık Kuruluşuna Başvuru ve Bilgi Alma Durumları & $\mathbf{n}$ & $\%$ \\
\hline \multicolumn{3}{|l|}{ Yaşanılan Gebelik Kaybında Sağlık Kuruluşuna Başvuru Durumu } \\
\hline Hayır & 25 & 13,4 \\
\hline Evet & 162 & 86,6 \\
\hline \multicolumn{3}{|l|}{ Başvurulan Sağlık Kuruluşu* } \\
\hline ASM & 4 & 2,5 \\
\hline Doğumevi & 16 & 9,9 \\
\hline Devlet Hastanesi & 74 & 45,7 \\
\hline Üniversite/EAH & 23 & 14,2 \\
\hline Diğer (Özel Muayenehane, Özel Hastane) & 49 & 30,2 \\
\hline \multicolumn{3}{|l|}{ Sağlık Kuruluşunda İlgilenen Sağlık Personeli* } \\
\hline Doktor & 149 & 34,3 \\
\hline Hemşire & 79 & 18,2 \\
\hline Ebe & 34 & 7,8 \\
\hline Diğer Personeller & 8 & 1,8 \\
\hline \multicolumn{3}{|l|}{ Sağlık Kuruluşunda Kayıp ile İlgili Bilgilendirme } \\
\hline Hayır & 81 & 50,0 \\
\hline Evet & 81 & 50,0 \\
\hline \multicolumn{3}{|l|}{ Sağlık Kuruluşunda Kayıp ile İlgili Düşüncelerin Paylaşımı } \\
\hline Hayır & 95 & 58,6 \\
\hline Evet & 67 & 41,4 \\
\hline \multicolumn{3}{|l|}{ Sağlık Kuruluşunda Kayba Yönelik Danışmanlık } \\
\hline Hayır & 100 & 62,1 \\
\hline Evet & 61 & 37,9 \\
\hline \multicolumn{3}{|l|}{ Danışmanlık Konuları* } \\
\hline Cinsel Yaşam / Aile Planlaması & 14 & 7,4 \\
\hline Kayıp Nedeni & 3 & 1,5 \\
\hline Kayıp Sonrası Süreç / Verilen Tedaviler & 5 & 2,6 \\
\hline Kanama Takibi /Hijyen /Beslenme & 26 & 13,8 \\
\hline Tıbbi İşlemler /Doğum Yöntemi & 3 & 1,5 \\
\hline Psikolojik Destek & 10 & 5,3 \\
\hline Genetik Tarama & 9 & 4,7 \\
\hline \multicolumn{3}{|l|}{ Kayıp ile İlgili Kayıtlı Olunan ASM Ebesi ile Görüşme } \\
\hline Evet & 77 & 44,5 \\
\hline Hayır & 96 & 55,5 \\
\hline \multicolumn{3}{|l|}{ Ebe ile Görüşülen Konu* } \\
\hline Aile Planlaması & 17 & 9,0 \\
\hline Kayıp Sonrası Süreç/ Kanama Takibi & 3 & 1,5 \\
\hline Kayıp Nedeni & 3 & 1,5 \\
\hline Genetik Tarama & 7 & 3,7 \\
\hline Psikolojik Destek & 11 & 5,8 \\
\hline Gebeliğin Kayıpla Sonuçlandığını Söyledim & 34 & 18,0 \\
\hline
\end{tabular}


* Birden fazla seçenek işaretlenmiştir.

Kadınlar gebelik kaybı ile ilgili ebelerin yaklaşımını $\% 11,8$ 'i çok iyi, $\% 16,8$ 'i iyi, $\% 12,8$ 'i orta olarak değerlendirirken $\% 55,4^{\prime}$ ü bilmiyorum şeklinde yanıtlamış ya da soruyu cevapsız bırakmıştır (Tablo 6).

Tablo 6. Kadınların gebelik kaybı ile ilgili ebelik yaklaşımına yönelik değerlendirmelerinin dağglımı $(\mathrm{n}=188)$

\begin{tabular}{lll}
\hline Kayıp ile İlgili Ebenin Yaklaşımını Değerlendirme & $\mathrm{n}$ & $\%$ \\
\hline Çok İyi & 22 & 11,8 \\
İyi & 30 & 16,8 \\
Orta & 24 & 12,8 \\
Kötü & 5 & 2,7 \\
Çok Kötü & 1 & 0,5 \\
Bilmiyorum / Cevapsız & 106 & 55,4 \\
\hline
\end{tabular}

Kadınların gebelik kaybı yaşama durumuna göre ebelik yaklaşımı hakkında beklentileri karşılaştırılmıştır. Prenatal kayıp yaşayan kadınlar ile kayıp yaşamayan kadınların ebelik yaklaşımına ilişkin olumlu iletişim beklentisi her iki grup açısından benzer bulunmuştur $(\mathrm{p}=0,139)$. Psikolojik destek $(p=0,001)$, danışmanlık $(p=0,004)$ ile eğitim $(p=0,016)$ beklentilerine bakıldığında prenatal kayıp yaşayan kadınlar ile kayıp yaşamayan kadınlar arasındaki farkın anlamlı olduğu, kayıp yaşayan kadınların yaşamayan kadınlara göre psikolojik destek, danışmanlık ve eğitim beklentilerinin daha fazla olduğu görülmüştür. Prenatal kayıp yaşayan kadınlar ile kayıp yaşamayan kadınların ebelik yaklaşımına ilişkin izlem $(p=0,935)$ ve bakım beklentisi $(p=0,067)$ ise her iki grup açısından benzer bulunmuştur (Tablo 7).

Tablo 7. Kadınların gebelik kaybı yaşama durumuna göre ebelik yaklaşımı hakkında beklentilerinin karşılaştırılması

\begin{tabular}{|c|c|c|c|c|c|c|}
\hline \multirow[t]{2}{*}{$\begin{array}{l}\text { Ebelik Yaklaşımına İlişkin } \\
\text { Beklentiler }\end{array}$} & \multicolumn{2}{|c|}{$\begin{array}{c}\text { Prenatal Kayıp } \\
\text { Yaşayan Kadınlar } \\
\qquad(\mathbf{n}=\mathbf{1 8 8})\end{array}$} & \multicolumn{2}{|c|}{$\begin{array}{c}\text { Prenatal Kayıp } \\
\text { Yaşamayan Kadınlar } \\
\qquad(n=246)\end{array}$} & \multirow{2}{*}{$\begin{array}{c}\text { Test } \\
\text { Değeri } \\
X^{2}\end{array}$} & \multirow[b]{2}{*}{$\mathbf{p}$} \\
\hline & $\mathbf{n}$ & $\%$ & $\mathbf{n}$ & $\%$ & & \\
\hline Olumlu iletişim & 148 & 78,7 & 189 & 84,4 & 2,193 & $\mathrm{AD}$ \\
\hline Psikolojik destek & 66 & 35,1 & 45 & 20,1 & 11,711 & 0,001 \\
\hline Danışmanlık & 34 & 18,1 & 19 & 8,5 & 8,409 & 0,004 \\
\hline İzlem & 7 & 3,7 & 8 & 3,6 & 0,007 & $\mathrm{AD}$ \\
\hline Eğitim & 58 & 30,9 & 46 & 20,5 & 5,764 & 0,016 \\
\hline Bakım & 8 & 4,3 & 3 & 1,3 & 3,345 & $\mathrm{AD}$ \\
\hline
\end{tabular}

\section{$\mathrm{AD}$, Anlamlı değil.}

\subsection{Tartışma}

$\mathrm{Bu}$ araştırmada kadınların prenatal kayıp durumunda ebelerden beklentileri ortaya konmuştur. Araştırmaya katılan kadınların büyük bölümü ilkokul mezunu, herhangi bir işte çalışmakta ve sosyal güvencesi bulunmaktadır. İlk evlilik yaşı 21 olarak saptanmıştır. Demografik özellikler TNSA 2018 verileri ile karşılaştırıldığında ülke genelinde, İstanbul ili genelinde ve Batı Marmara Bölgesinde ki kadınlar ile benzer bulunmuştur.

Kadınların önemli bir bölümü gebelik geçirmiş ve gebelikleri planlıdır. Kadınların toplam gebelik sayısı ortalamas1 3,0土1,9'dur ve kadınların \%51,1'i 1 ile 2 gebelik, \%48,9'u 3 ve üzeri gebelik geçirdiğini belirtmiştir. Yılmaz (2010)'ın çalışmasında planlı gebelik oranı gebelik sayılarına ilişkin oranlar benzerlik göstermektedir. Araştırmaya katılan kadınların yarısının gebelik kaybı yaşadığı, kayıp yaşayan kadınların yaşadıkları kayıp türü oranları en yüksekten düşüğe kendiliğinden düşük, isteğe bağlı düşük ve ölü doğum olarak saptanmıştır. Kayıp

yaşayan kadınların yaşadıkları gebelik kaybının nedenine ilişkin bilgileri incelendiğinde çoğunun kayıp nedenini bilmediği, kayıp sürecinde destek aldıkları kişiler sorgulandığında önemli bir bölümü eşinden ve aile üyelerinden destek alırken azımsanamayacak oranda kadının ise hiç kimseden destek almadığı görülmüştür. Akan (2006)'ın çalışmasında kadınların gebelik kaybı oranları çalışmamızla benzer bulunmuş olup gebelik kaybı yaşayan kadınların yüksek oranda gebeliklerinin spontane düşükle sonlandığını bildirilmiştir. TNSA 2018 verilerine göre ülkemizde istemsiz düşük oranı yüzde 13,0 olup, isteyerek düşük oranı yüzde 6,0 ve ölü doğum oranı ise yüzde 1,0 olarak bildirilmiştir. Bu oranlara göre 
2008 yılından sonraki dönemlerde kendiliğinden düşük oranlarında artış olduğu görülürken isteyerek düşük ve ölü doğum oranlarında düşüş olduğu görülmektedir. Çalışmamızın yapıldığı yer kırsaldan yoğun göç alan ve sosyo-demografik özellikler açısından yetersiz bir bölge olması, aynı zamanda sosyo-ekonomik düzeyi iyi olan kişilerin daha çok özel kurumlardan hizmet almayı tercih etmesi nedeniyle oranların genele göre yüksek bulunması beklenen bir durumdur.

Araştırmada kadınların gebelik kaybının nedenleri oranları yüksekten düşüğe doğru ağr1/kanama, fizyolojik nedenler (hipertansiyon vb.), kendi istemiyle, ağır kaldırma/düşme, fetal nedenler (gelişim geriliği, anomali vb.) ve psikolojik nedenler (stres, üzüntü vb.) şeklinde sıralanmıştır. Yüksek oranda kadının kayıp nedenini bilmediği görülmüştür.

Kayıp yaşanılan dönemde kadınların destek aldıkları kişiler en fazla eş ve aile üyeleri olarak saptanmış ve önemli oranda kadının hiç kimseden destek almadığ tespit edilmiştir. Literatürde kayıplar üzerine yapılan tüm çalışmalarda kayıp ve sonraki süreçte çok yönlü şekilde desteklenmesinin önemi vurgulanmaktadır [6, 18]. Kadınların sonraki yaşam deneyimlerinde yaşanılan kayıpların izlerini taşıdıkları, destek sistemleri güçlü ve aktif kullanabilen kişilerin kayıptan sonra daha hızl toparlandıkları, hayata daha kolay adapte oldukları ve kayıptan sonraki gebelikler üzerine olumlu etkilerinin olduğu çok sayıda çalışma ile kanıtlanmıştır $[1,2,7,11$, $16,21,22]$.

Kadınların çoğunluğu yaşanılan gebelik kaybı ile ilgili sağlık kuruluşuna başvuruda bulunmuş ve en fazla devlet hastanesi ile özel kurumlara başvurdukları sonucuna ulaşılmıştır. Gebelik kaybı sürecinde çoğunluğunun başvurulan sağlık kuruluşunda kendisi ile ilgilenen sağlık personelinin doktor olduğu tespit edilmiştir. Bu oranları İstanbul genelinde devlet hastanelerinin doluluk oranının fazla olmasına, devlete bağlı sağlık kurumlarında yoğunluk ve personel sayısının yetersizliği nedeniyle ihtiyaç duydukları ilgi alakayı görememelerinin sonucunda doktor ile doğrudan bağlantı kurabilecekleri özel kurumlara yönelmelerine bağlayabiliriz. Aynı zamanda görüșmeler sırasında kadınların verdiği yanıtlardan yola çıkılarak sağlık kurumlarında hizmet veren personellerin kendilerini tanıtmadıkları, yaptıkları işlemi açıklamadıkları ve hizmet alan kişilerin sağlık çalışanlarının mesleklerine ilişkin bilgi eksiklikleri olduğu, bu nedenle de kendileriyle ilgilenen personeli ayırt etmekte zorlandıkları düşünülebilir. Kayıp yaşayan kadınların büyük bir bölümünün başvurdukları sağlık kuruluşunda gebelik kaybı ile ilgili düşüncelerini paylaşamadığı ve danışmanlık alamadığı saptanmıştır. Danışmanlık alan kadınların aldığı danışmanlık konusu daha çok kayıp sonrası kanama takibi/ hijyen/ beslenme ile AP/cinsel yaşam şeklindedir. Çalışma verilerimiz bölgedeki kadınların kendilerine yapılan tüm bilgilendirmeleri danışmanlık şeklinde algıladıklarını gösterirken, yapılan görüşmeler sırasında edinilen izlenimler ile birleştirildiğinde kayıp sürecinde bilgi ihtiyaçlarının fazla olduğunu ortaya koymaktadır. Sağlık profesyonelleri kayıp yaşayan kadın ile yakın çevresinde bulunan bireylerin konuyla ilgili dini ve kültürel yaklaşımlarını bilişsel, duygusal ve sosyal yönden irdelemelerine yardımcı olmalıdır [3]. Literatürde kayıplar üzerine yapılan çok sayıda çalışmaya baktığımızda da kayıp yaşayan kişilerin kayıp sırasında ve sonrasında sağlık çalışanlarının desteğine fazlasıyla ihtiyaç duyduğunu göstermektedir $[1,4,6$, 13].Kadınların önemli bir bölümünün gebelik kaybı yaşanılan süreçte, bağlı bulunduğu ASM ebesi ile görüşme yapmadığı, görüşme yapan kadınların hangi konularda görüşme yaptığını incelediğimizde büyük bir bölümünün gebeliğinin sonlandığını bildirdiği ve AP hakkında bilgi verildiği tespit edilmiştir. Kadınların gebelik kaybı ile ilgili ebelerin yaklaşımını nasıl değerlendirdiklerini incelediğimizde önemli bir bölümünün bilmiyorum ya da cevapsız biraktığ görülmüş, cevap verenlerin de ebelik yaklaşımını iyi ve orta şeklinde değerlendirdikleri sonucuna ulaşılmıştır. Birinci basamak sağlı kurumlarında girişimsel işlemlerin yapılmaması prenatal kayıp döneminde ASM'ye başvurma oranını doğrudan etkilediğinden görüşme yapanların oranının düşük bulunması olağandır. Çalıșmamızın kapsamı gereği yapılan görüşmelerde kadınların önemli bir bölümü Aile Hekimliği sisteminden önce kayıp yaşadığını dolayısıyla ASM ebesi ile görüşme yapmadığını, bir bölümü kayıp

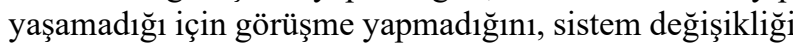
sonrasında kayıp yaşayanlar ise yüksek oranda ebesini kendisi aradığını ve kayıp yaşadığı bilgisini verdiğini belirtmiştir. Buna istinaden ilgili sorunun $\% 55,4$ oranda kadın tarafından bilmiyorum şeklinde ya da cevapsız olarak bırakmaları olağandır. $\mathrm{Bu}$ veriler doğrultusunda ve kadınlarla yapılan görüşmelerde alınan cevaplara ilişkin birinci basamak sağlık hizmetleri kapsamında kadın sağlığının korunması ve yükseltilmesi hususunda bilgilendirilme, danışmanlık ile izlem ihtiyaçlarının giderilmesi noktasında etkinliğinin yetersiz olduğu, kayıp sonrası süreçte kadınların ASM ebeleriyle iletişimin sıklıkla uzaktan sağladığı dolayısıyla yeterli desteği alamadıkları düşünülebilir. Aynı zamanda iletişimin uzaktan sağlanmasının nedeni bölge nüfusunun fazla olması gerekçesiyle sağlık personeli başına düşen kişi sayısının yüksek olması ve birinci basamak sağlık sistemi performans puanı hesaplamalarında bilgilendirme, danışmanlık, eğitim gibi konulara ve kayıp sonrası izleme yer verilmemiş olması ile açıklanabilir.

Prenatal kayıp yaşayan kadınlar ile kayıp yaşamayan kadınların ebelik yaklaşımına ilişkin analizlerinde olumlu iletişim beklentisi her iki grup açısından benzer bulunmuştur. $\mathrm{Bu}$ durumda hizmet alan tüm kadınlar ebelerden olumlu iletişim beklemektedir denilebilir. Psikolojik destek, danışmanlık ile eğitim beklentilerine bakıldığında prenatal kayıp yaşayan kadınlar ile kayıp yaşamayan kadınlar arasındaki istatistiksel farkın anlamlı olduğu, kayıp yaşayan kadınların yaşamayan kadınlara göre psikolojik destek, danışmanlık ve eğitim beklentilerinin daha fazla olduğu tespit edilmiştir. Bu durum kayıp yaşamayan kadınların hiç gebelik ve/ veya kayıp deneyimi yaşamamış olmaları nedeniyle kayıp 
yaşayan kadınların duygularına ilişkin empati kuramamalarından kaynaklanmış olabilir. Gebelik kaybının yaşandığı süreçte kadın ve ailesinin yaşadığ duygulanımlar şiddetli, karmaşık, uzun süreli olabilmekte ve bu uzun dönemde yaşanan emosyonel değişiklikler bireyden bireye farklılıklar gösterebilmektedir $[9,12]$. Kadın ve ailesinin her şeye yeniden başlamaları ve yeniden yapılanmaları, onların 624 aylarını almaktadır. Bunun için gereken zaman gebelik süresinin uzunluğuna değil, bireylerin güçlerine, baş etme stratejilerine, destek arama yeterliliği ile desteği kabul etmesine ve o anda yaşanan stresörlere bağlıdır [9]. Çalışmamızda da kadınların psikolojik destek ihtiyaçlarının gebelik kaybı yaşayan kadınlarda, kayıp yaşamayan kadınlara göre istatistiksel olarak anlamlı derecede fazla bulunması diğer çalışmalar ile benzerdir. Gebelik kaybı yaşayan kadınların çalışma sırasında vermiş olduğu cevaplardan daha çok sonraki gebelik planlamaları ile ilişkili danışmanlık gereksinimlerinin ve bilgilendirilme ihtiyaçlarının olduğu görülmüş, danışmanlık ve eğitim ihtiyaçları analiz edildiğinde de istatistiksel farkın anlamlı olduğu saptanmıştır. Konuya ilişkin yapılan araştırmalar, ailelerin kayıp süreci ve kayıp sonrası süreçte yaşadıkları, ihtiyaçları ve beklentilerinin kadın ve aile sağlığına olumsuz etkileri, gelecek gebeliklere, doğum ve doğum sonrası sürece hatta daha sonra ki süreçlere kadar yansıdığını göstermektedir [1, 7, 11, 15, 16, 21, 22].

Prenatal kayıp yaşayan kadınlar ile kayıp yaşamayan kadınların ebelik yaklaşımına ilişkin izlem ve bakım beklentisi ise her iki grup açısından benzer olarak saptanmıştır. $\mathrm{Bu}$ sonuca göre her iki grubun da izlem ve bakım ihtiyacı duyduğunu söyleyebiliriz. Çalışmamız olumlu iletişim, psikolojik destek, izlem, bakım gibi parametrelerde diğer çalışmalar ile benzerlik göstermektedir [1].

\section{Sonuc}

Araştırmaya katılan kadınların gebelik kaybı ile ilgili sağlık kuruluşuna başvuru oranı oldukça yüksek olup, kayıp yaşayan kadınların büyük bir bölümünün başvurdukları sağlık kuruluşunda gebelik kaybı ile ilgili düşüncelerini paylaşamadığı ve danışmanlık alamadığ sonucuna ulaşılmıştır. Gebelik kaybı yaşayan kadınların çalışma sırasında vermiş olduğu cevaplardan daha çok sonraki gebelik planlamaları ile ilişkili danışmanlık gereksinimlerinin ve bilgilendirilme ihtiyaçlarının olduğu görülmüş, danışmanlık ve eğitim ihtiyaçları analiz edildiğinde de istatistiksel farkın anlamlı olduğu saptanmıştır. Prenatal kayıp yaşayan kadınlar ile kayıp yaşamayan kadınların ebelik yaklaşımına ilişkin izlem ve bakım beklentisi ise her iki grup açısından benzer olarak saptanmıştır. Bu sonuca göre her iki grubun da izlem ve bakım ihtiyacı duyduğu söylenebilir

\section{Referanslar}

1.Akan, S, Tıbbi Abortus Yapan Kadınların Yaşadığı Psiko-Sosyal Sorunlara İlişkin Nitel Bir Çalışma, Yüksek Lisans Tezi, İstanbul Üniversitesi Sağlık Bilimleri Enstitüsü, İstanbul 2006

2. Armstrong, D.S, Perinatal Loss and Parental Distress After the Birth of a Healthy Infant, Advences in Neonatal Care, 2007, 7(4), 200-206.
3. Beji, N.K, Kadın Sağlığı ve Hastalıkları, İstanbul, 2015, pp 61-63.

4. Bucak, F, Toker, E, Asoğlu, M, Terapötik Abortus Uygulanan Kadınların Durumluk-Sürekli Anksiyete Düzeyleri ve İlișkili Faktörler, Sağllk Akademisyenleri Dergisi, 2018, 256-263.

5. Côté-Arsenault, D, Morrison-Beedy, D, Women's Voices Reflecting Changed Expectations for Pregnancy After Perinatal Loss, Journal of Nursing Scholarship, 2001, 33(3), 239-244.

6. Çam, M.O, Tektaş, P, Gebelik Kaybında Hemşirelik Yaklaşımı, Uluslararası Hakemli Kadın Hastalıkları ve Anne Çocuk Sağlığ Dergisi, 2015, 6, 105-122.

7. Demirel, F, Ates, S, Sevket,, O, Yaşar L, Savan, K, Tekrarlayan Gebelik Kayıpları Sonrası Oluşan Gebeliklerin Seyri, Pamukkale Tıp Dergisi, 2014, 7(1), 41-45.

8. Dikencik, B.K, Akın, N, Yavan, T, Coşkun, A, Emotional Reactions of Parents Who Experiences Baby Loses in the Perinatal Period and Nursing Approach to This Problem, Perinatoloji Dergisi, 1999, 7(1), 9-14.

9. Gilbert, E.S, Manual of High Risk Pregnancy \& Delivery, Arizona, 2011, pp 149-165.

10. Hutti, M.H, Social and Professional Support Needs of Families After Perinatal Loss, Journal of Obstetric, Gynecologic \& Neonatal Nursing, 2005, 34(5), 630-638.

11. Iles, S, Gath, D, Psychiatric Outcome of Termination of Pregnancy for Foetal Abnormality, Psychological Medicine, 1993, 23(2), 407413.

12. Körükcü ,Ö, Kukulu, K, Perinatal Kayıp ve Ebeveynlere Yansıması, Dicle Tip Dergisi, 2010, 37(4), 429-433.

13. Lamb, E.H, The Impact of Previous Perinatal Loss on Subsequent Pregnancy and Parenting, Journal of Perinatal Education, 2002, 11(2), 33-40.

14. Sağlık Bakanlığı Sağlık İstatistikleri Yıllığı, 2018, Ankara, 2019, 24.

15. Sak, M.E, Evsen, M.S, Soydinç, H.E, Sak, S, Başaranoğlu, S, Yalınkaya, A. Bir Bölge Hastanesinde Ölü Doğum Olgularının Retrospektif Analizi, Perinatoloji Dergisi, 2012, 20(3),135-139.

16. Seyhan, A, Ata, B, Urman, B, Tekrarlayan Gebelik Kayılarına Kanıta Dayalı Yaklaşım, Türk Jinekoloji ve Obstetrik Derneği Dergisi, 2011, 8(1), 5- 20.

17. Sutan, R, Amin, R.M, Arifin, K.B, Teng, T.Z, Kamal, M.F, Rusl1, R.Z, Psychosocial Impact of Mothers with Perinatal Loss and Its Contributing Factors: an Insight, Journal of Zhejiang University Science B (Biomed \& Biotechnol), 2010, 11(3), 209-217.

18. Sutan, R, Miskam, H.M, Psychosocial Impact of Perinatal Loss Among Muslim Women, BMC Women's Health, 2012, 12(1), 1-9.

19. Taşkın, L, Doğum ve Kadın Sağlığı Hemşireliği, Ankara, 2016, pp 15-16.

20. Türkiye Nüfus ve Sağlık Araştırması 2018, Hacettepe Üniversitesi Nüfus Etüdleri Enstitüsü, Ankara, 2019, 45-163.

21. Yılmaz, S.D, Perinatal Kayıp Deneyiminin Sonraki Gebelik Üzerine Etkileri, Doktora Tezi, İstanbul Üniversitesi Sağlık Bilimleri Enstitüsü, İstanbul, 2010.

22. Yilmaz, S.D, Beji, N.K, Effects of Perinatal Loss on Current Pregnancy in Turkey. Midwifery 2013, 29(11), 1272-1277.

http://edergi.cbu.edu.tr/ojs/index.php/cbusbed isimli yazarın CBU-SBED başlıklı eseri bu Creative Commons Alıntı-Gayriticari4.0 Uluslararası Lisansı ile lisanslanmıştır.

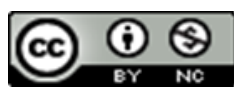

